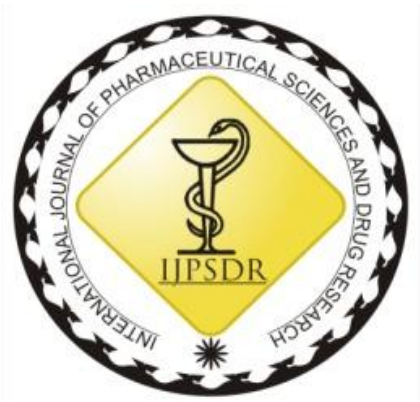

ISSN: 0975-248X

RESEARCH ARTICLE CODEN (USA): IJPSPP

$(\mathrm{cc})$ EY-NC-SA

\title{
Effect of Synthetic Red Dye Orange Red and Natural Red Dye Alizarin on Biochemical and Hematological Parameters in Male Wistar Rats
}

\author{
Ishfaq Shafi Khan, Md Niamat Ali*, Mohd Murtaza \\ Cytogenetics and Molecular Biology Research Laboratory, Centre of Research for Development, University of Kashmir, \\ Srinagar-190006, Jammu and Kashmir, India
}

Copyright (C) 2019 Ishfaq Shafi Khan et al. This is an open access article distributed under the terms of the Creative Commons AttributionNonCommercial-ShareAlike 4.0 International License which allows others to remix, tweak, and build upon the work non-commercially, as long as the author is credited and the new creations are licensed under the identical terms.

\begin{abstract}
Nowadays synthetic food dyes are mostly preferred than natural plant derived dyes due to low cost and intense coloration. In this study hematological and biochemical parameters were determined in male wistar rats after 30 days treatment with synthetic red dye orange red and natural plant derived red dye alizarin. 25 male wistar rats were divided into 5 groups with 5 animals per group. Group I rats were taken as control treated with normal rat diet and distilled water. Group II and III rats (experimental) were oral gavaged with $50 \mathrm{mg}$ and $150 \mathrm{mg} / \mathrm{kg}$ body weight of alizarin dye. Group IV and V rats (experimental) were gavaged with $50 \mathrm{mg}$ and $150 \mathrm{mg} / \mathrm{kg}$ body weight of orange red dye. Treatment of group $\mathrm{V}$ rats with $150 \mathrm{mg} / \mathrm{kg}$ body weight of orange red dye produce significant changes in $\mathrm{RBC}, \mathrm{Hb}, \mathrm{Hct}, \mathrm{MCH}$, serum aminotransferase enzymes and serum protein fraction. In comparison to this in group IV rats a significant change was observed only in $\mathrm{Hb}$, serum aminotransferase enzymes and serum protein fraction when compared with control (group I) rats. However in group II and III alizarin treated rats no significant change was observed in different biochemical and hematological parameters relative to their respective control. In conclusion synthetic orange red dye proved to be more toxic than natural plant derived red dye alizarin.
\end{abstract}

Keywords: Orange red dye, alizarin, hematological and biochemical parameters, wistar rats.

DOI: 10.25004/IJPSDR.2019.110511

Int. J. Pharm. Sci. Drug Res. 2019; 11(5): 221-225

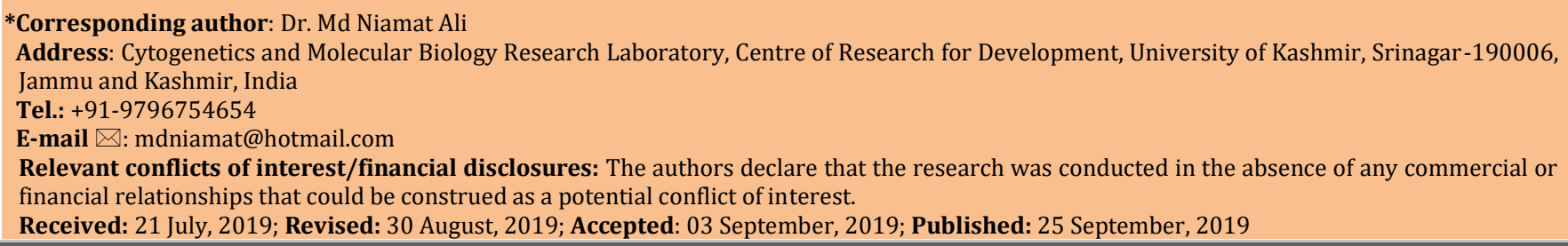

\section{INTRODUCTION}

From the last few decades there have been observed a tremendous increase in the usage of food additives mainly azo dyes due to increase in industrialization, population and new trends in food technology. Nowadays use of food dyes is an integral part of all food preparations and is mainly used to increase consumer attraction of food. [1] Food dyes are mainly used to change the physical condition of food stuff. Food dyes may be synthetic or natural plant derived but synthetic dyes are mostly preferred than natural dyes due to low cost and deep coloration. ${ }^{\text {[2] Natural }}$ 
dyes derived from plants are considered to be safe and also show potent antimicrobial activities. [3] During older times natural plant derived dyes were preferred food colorants but nowadays people use synthetic dyes due to their intense coloration and consumer attraction. Synthetic food colour additives are mostly azo dyes which when applied to food and drugs give new colour and make them more attractive and palatable. ${ }^{[4]}$ There are more than 3000 azo dyes which are nearly used in every sector like cosmetics, textile firms, leather, pharmaceutical industries, food and paper production industries. [5] Many food dyes have the capacity to induce chromosomal abnormalities in mammalian cells with increase in dosage and exposure time. ${ }^{[6]}$ The food items containing azo dyes have the potential to cause cancer. [7]

In our research work we select synthetic red coloured dye called orange red, which is a mixture of two azo colorants carmoisine and sunset yellow and natural red dye alizarin derived from roots of madder plant (Rubia tinctorum) and evaluate their effect on haematological and biochemical parameters in male albino wistar rats.

Orange red dye is an amalgamation of two azo colorants namely carmoisine and sunset yellow. Both these colorants are reported to be toxic. Carmoisine is Di-sodium salt of 2-(4 sulpho -1-naphthylazo)-1naphthol-4-sulphonic acid with chemical formulla $\mathrm{C}_{20} \mathrm{H}_{12} \mathrm{~N}_{2} \mathrm{Na}_{2} \mathrm{O}_{7} \mathrm{~S}_{2}$ and molecular weight $458.459 \mathrm{~g} / \mathrm{mol}$. Although use of carmoisine is allowed in UK and India but it is not permitted in US. Regarding the toxicological status of carmoisine it was concluded that, high doses of carmoisine cause liver damage and also lowers the expression of some key enzymes. ${ }^{[8]}$ However in one research finding it was found that carmoisine causes chromosomal aberrations in bone

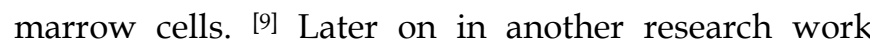
carmoisine was found to be safe in both in vitro and in vivo experiments. [10]

Sunset yellow (E 110) is an orange red coloured azo dye with chemical formula of $\mathrm{C}_{16} \mathrm{H}_{10} \mathrm{~N}_{2} \mathrm{Na}_{2} \mathrm{O}_{7} \mathrm{~S}_{2}$ and molecular weight $452.37 \mathrm{~g} / \mathrm{mol}$. In regard of sunset yellow an admissible daily intake (ADI) of $2.5 \mathrm{mg} / \mathrm{kg}$ was approved by the joint expert committee on food additives (JECFA) according to a three month experimental report in rats. It was reported that significant testicular toxicity was produced in rats when treated with sunset yellow at dose concentration of 250 and $1500 \mathrm{mg} / \mathrm{kg}$ for 90 days. ${ }^{[11]}$ The toxicological status of sunset yellow receives both positive and negative mutagenic reviews. Lack of any toxicity report was observed in albino mice when dye sunset yellow was administered orally twice at 24 hours interval. [12] In an in vivo micronucleus assay in mice, sunset yellow at single dose concentration of $2000 \mathrm{mg} / \mathrm{kg}$ was found to be antimutagenic in action. [13]

During older times people mostly use plant derived alizarin as red coloring dye for food and textiles. Alizarin is an anthraquinone red dye pigment derived from roots of Rubia tinctorum commonly known as madder plant. [14] Chemically alizarin is 1,2dihydroxyanthraquinone; 1,2- dihydroxy- 9,10anthracenedione with molecular formulla $\mathrm{C}_{14} \mathrm{H}_{18} \mathrm{O}_{4}$. It was reported that alizarin contain antimicrobial and antifungal activities. ${ }^{[15]}$ However with advancement in food technology people start to replace use of natural red dye alizarin with synthetic red dyes. In this research work we made efforts to evaluate and compare the haematological and biochemical parameters in male albino wistar rats treated with natural red dye alizarin derived from roots of madder plant and synthetic orange red dye.

\section{MATERIALS AND METHODS}

\section{Experimental Animals}

In our study 25 mature male albino wistar strain rats (Rattus norvegicus) weighing about 150- 200 grams were used. These rats were procured from Indian Institute of Integrative Medicine (IIM), Canal Road Jammu. The animals were housed in stainless steel cages in the animal house of Zoology department, University of Kashmir under laboratory conditions at temperature 24 $\pm 2^{\circ} \mathrm{C}$ and $12 / 12$ hours of light and dark cycle. The animals were first acclimatized for about one week and were starved for 50 minutes before the start of experiment. The approval for the experimental study was sanctioned by Institutional Animal Ethical Committee, and the whole experiment setup was performed as per the ethical laws of CPCSEA rules.

\section{Chemicals}

Synthetic orange red dye (mixture of carmoisine and sunset yellow) was procured from local market under fssai license. Alizarin dye and other chemicals used in this study were of high analytical grade. A stock solution was prepared by dissolving the orange red dye and alizarin separately in $1000 \mathrm{ml}$ of double distilled water. The dose concentration was maintained in such a way that the amount of orange red dye and alizarin administered per animal was according to their respective weight.

\section{Dosage and Design of Experimental Animals}

The rats were randomly divided into 5 groups, each group comprise of 5 animals. The animals from each group were weighed on the first day of experiment and after the completion of experiment. The dose was given mostly in morning time between 9.30- 10.30 a.m. The animals were treated with the test chemical orally by gavage intubation once a day for 30 days. The animals were starved for about 12 hours before start of the treatment protocol.

Group I: (control group) treated with normal rat feed and distilled water.

Group II: Rats in this group were treated with low dose of alizarin $50 \mathrm{mg} / \mathrm{kg} \mathrm{b}$. wt/day orally for 30 days.

Group III: Rats in this group were treated with high dose of alizarin $150 \mathrm{mg} / \mathrm{kg} \mathrm{b}$. wt/day orally for 30 days. 
Group IV: Rats in this group were treated with low dose of orange red dye $50 \mathrm{mg} / \mathrm{kg} \mathrm{b}$. wt/day orally for 30 days.

Group V: Rats in this group were treated with high dose of orange red dye $150 \mathrm{mg} / \mathrm{kg} \mathrm{b.} \mathrm{wt/day} \mathrm{orally} \mathrm{for}$ 30 days.

\section{Biochemical Analysis}

Blood samples were collected from all group of rats and allowed to clot at room temperature in dry glass centrifuge tubes and centrifuged at $3500 \mathrm{rpm}$ for 13 minutes. The supernatant serum obtained was used to estimate biochemical parameters. Alanine aminotransferase (ALT) and aspartate aminotransferase (AST) were estimated by the method of [16], Serum alkaline phosphatase (ALP) was determined according to protocol of [17], Serum total protein and serum albumin concentrations were determined according to method of [18], Serum globulin was calculated by [19].

\section{Haematological Analysis}

A part of blood samples were collected in heparinized tubes for hematocrit value, which was determined by the method. [20] Another part of blood was collected in EDTA for the haematological experimentation. The red blood cells (RBCs) and white blood cells (WBCs) counts were estimated by Neubauer haemocytometer method. The hemoglobin $(\mathrm{Hb})$ concentration was determined according to [21], using the cyanomethaemoglobin method. Mean corpuscular hemoglobin $(\mathrm{MCH})$ and mean corpuscular volume $(\mathrm{MCV})$, were determined according to [21]

\section{Statistical Analysis}

All values were calculated by taking mean values with \pm standard deviation. The results were evaluated by

Table 1: Effect of 30 days treatment with $50 \mathrm{mg}$ and $150 \mathrm{mg} / \mathrm{kg}$ bw of orange red dye and alizarin on haematological parameters in male wistar rats

\begin{tabular}{|c|c|c|c|c|c|c|}
\hline Groups & RBC (x106/mm $\left.{ }^{3}\right)$ & $\mathrm{Hb}(\%)$ & Hct (\%) & MCV (fl) & MCH (pg) & WBC $\left(\times 10^{3} / \mathrm{mm}^{3}\right)$ \\
\hline I (Control) & $8.09 \pm 1.01$ & $14.47 \pm 1.20$ & $44.47 \pm 4.69$ & $54.01 \pm 5.32$ & $18.34 \pm 2.37$ & $6.64 \pm 1.95$ \\
\hline II (Alizarin) & $7.70 \pm 0.82$ & $13.60 \pm 1.19$ & $43.58 \pm 4.76$ & $53.22 \pm 5.50$ & $17.50 \pm 2.35$ & $6.48 \pm 1.73$ \\
\hline III (Alizarin) & $7.10 \pm 1.29$ & $12.80 \pm 1.50$ & $42.88 \pm 4.50$ & $52.62 \pm 5.64$ & $16.90 \pm 2.66$ & $7.34 \pm 1.59$ \\
\hline IV (Orange red) & $6.67 \pm 1.56$ & $12.26 \pm 1.17^{*}$ & $42.20 \pm 4.41$ & $51.96 \pm 5.56$ & $16.42 \pm 2.59$ & $7.54 \pm 1.44$ \\
\hline V (Orange red) & $5.27 \pm 1.86^{*}$ & $10.66 \pm 0.88^{* *}$ & $40.25 \pm 4.41^{*}$ & $50.02 \pm 5.42$ & $14.7 \pm 3.00^{*}$ & $10.44 \pm 0.49^{* *}$ \\
\hline
\end{tabular}

Values are expressed as mean \pm SD of five animals per group. RBC: Red blood cell, Hb: Hemoglobin, Hct: Hematocrit, MCV: Mean corpuscular volume, MCH: Mean corpuscular hemoglobin, WBC: White blood cell; Level of significance: * significant, ** highly significant

Table 2: Effect of 30 days treatment with $50 \mathrm{mg}$ and $150 \mathrm{mg} / \mathrm{kg} \mathrm{bw}$ of orange red dye and alizarin on some liver specific serum enzymes in male albino Wistar rats.

\begin{tabular}{|c|c|c|c|}
\hline Groups & ALT (U/L) & AST (U/L) & $\operatorname{ALP}(\mathrm{U} / \mathrm{L})$ \\
\hline I (Control) & $28.14 \pm 3.52$ & $48.82 \pm 2.77$ & $64.4 \pm 15.70$ \\
\hline II (Alizarin) & $28.99 \pm 3.61$ & $55.10 \pm 3.14^{*}$ & $66.76 \pm 1.51$ \\
\hline III (Alizarin) & $30.98 \pm 3.78$ & $57.96 \pm 3.69^{*}$ & $72.56 \pm 3.18$ \\
\hline IV (Orange red) & $60.40 \pm 3.64^{* *}$ & $62.66 \pm 4.50^{* *}$ & $130.0 \pm 12.74^{* *}$ \\
\hline V (Orange red) & $90.0 \pm 15.81^{* *}$ & $70.84 \pm 6.36^{* *}$ & $146.0 \pm 20.73^{* *}$ \\
\hline
\end{tabular}

All values are expressed as mean \pm SD; ALT $=$ Alanine aminotransferase, $A S T=$ Aspartate aminotransferase, $\mathrm{ALP}=\mathrm{Alkaline}$ phosphatase

Level of significance: ${ }^{*}$ significant, ${ }^{* *}$ highly significant

Table 3: Effect of 30 days treatment with $50 \mathrm{mg}$ and $150 \mathrm{mg} / \mathrm{kg}$ bw of orange red dye and alizarin on serum total protein, albumin and globulin in male albino Wistar rats.

\begin{tabular}{|c|c|c|c|}
\hline Groups & Serum total protein $(\mathrm{g} / \mathrm{dl})$ & Serum albumin (g/dl) & Serum globulin (g/dl) \\
\hline I (Control) & $7.44 \pm 0.52$ & $4.20 \pm 0.49$ & $2.48 \pm 0.39$ \\
\hline II(Alizarin) & $8.80 \pm 0.23$ & $5.82 \pm 0.25$ & $3.84 \pm 0.60$ \\
\hline III(Alizarin) & $9.32 \pm 0.23$ & $6.28 \pm 0.57$ & $4.24 \pm 0.65$ \\
\hline IV(Orange red) & $11.66 \pm 1.89^{*}$ & $7.97 \pm 1.89^{*}$ & $6.96 \pm 2.26^{*}$ \\
\hline V(Orange red) & $14.81 \pm 2.45^{* *}$ & $9.91 \pm 1.39 *$ & $8.27 \pm 0.82^{*}$ \\
\hline
\end{tabular}

Values are expressed as mean \pm SD. Level of significance: * significant, ${ }^{* *}$ highly significant 
Table 3 shows the effect of orange red dye and alizarin on serum total protein, albumin and globulin levels in male wistar rats. The two doses $50 \mathrm{mg}$ and $150 \mathrm{mg} / \mathrm{kg}$ bw of orange red dye produce a significant increase $(p<0.05)$ in level of total protein, albumin and globulin when compared with the control group. However in group II and III rats treated with low and high dose of alizarin a statistically insignificant change was detected when compared with (group I) rats.

\section{DISCUSSION}

Food dyes are important component of food in this present fast life. They are added to food for increasing consumer attraction and making it more palatable. [22] Coloring dyes are important kind of food additives synthesized or extracted from plants or other sources. [23] Synthetic food dyes are nowadays considered one of the prime suspects for causing cancer. [24] According to IARC (1983) most of the food coloring agents are toxic and are causing many types of damages in mammalian cells. Therefore more and more attention has been made to focus on short and long term toxicity, carcinogenicity and metabolic studies in view of food dyes. ${ }^{25]}$ However the plant derived natural dyes are considered as safe and also possess antimicrobial activities.

In this research work, an attempt was made to find out the effect of synthetic orange red dye and natural red dye called alizarin derived from roots of madder plant on hematological and biochemical parameters in male albino wistar rats. The dye orange red that we use in food is actually a mixture of two primary colorants carmoisine and sunset yellow both of these primary colorants have been listed as permitted food dyes. There are both positive and negative reports regarding toxicity of carmoisine and sunset yellow individually, but no research work had been done yet in view of toxicity of orange red dye.

Hematological parameters are considered important tools for assessing damage caused by certain chemicals. It is used for calculation of blood indices like RBC, $\mathrm{MCV}, \mathrm{MCH}, \mathrm{Hb}, \mathrm{Hct}, \mathrm{WBC}$ etc. Decreased RBC value is usually considered an anemia condition.

The present investigation showed that rats treated with high dose of orange red dye produce a significant decrease in $\mathrm{RBC}$ count, $\mathrm{Hb}$, Hct and $\mathrm{MCH}$ values in comparison to control rats. However group II and III rats which were treated with low and high dose of natural red dye alizarin didn't produce any significant change in different blood indices when compared with control group rats. The decline of different blood parameters may be due to inhibition of hematopoietic organ system. The hematopoietic organs are considered most sensitive system to assess the toxicity of chemicals. [26] Due to orange red dye chemicals the hematopoietic organs may get affected and became unable to release normal RBCs and thus can be responsible for decline in different blood parameter values. The present investigation was in accordance with the finding of [27], who observes a decrease in value of different blood indices when albino rats were treated with allura red dye.

Furthermore it was reported that a significant increase in the value of WBCs was observed in rats treated with high dose of orange red dye and no significant change in WBC value was observed in alizarin treated rats when compared with control group. The increase in WBC count in rats treated with orange red dye may be due to activation of immune system in response to cellular damage caused by any chemical. [28]

Normally serum aminotransferase enzymes are considered as markers of liver damage caused by chemicals. [29] Increase in concentration of these serum enzymes is recognized as early sign of liver hepatitis. The present investigation study revealed that rats treated with both low and high dose of orange red dye produce highly significant increase $(p<0.01)$ in serum ALT, AST and ALP activities when compared with group I rats (control). The elevation in concentration of these enzymes has been considered as indicators of liver damage. The present reports are in accordance with [30], who found that low and high doses of some synthetic dyes carmoisine, sunset yellow, erythrosine, ponceau, tartrazine, indigotine, fast green, brilliant blue and brilliant black produce an increase in level of AST, ALT and ALP. Furthermore these results coincides with the results of [31], who found that rats whose diets were supplemented with chocolate colors A and B show an increase in the level of serum aminotransferase enzymes. In contrast to this alizarin dye treated rats didn't produce any significant change in ALT and ALP except AST value which was considered as significant change when compared with control rats. The increase in concentration of serum aminotransferase enzymes due to orange red dye treatment may be due to hepatic damage which subsequently caused the release of these liver specific enzymes in greater concentration.

Our work revealed that rats administered with $50 \mathrm{mg}$ and $150 \mathrm{mg} / \mathrm{kg}$ bw of orange red dye produce a significant change in serum total protein, serum albumin and serum globulin levels when compared with their respective control rats. On the other side rats treated with different doses of alizarin produce insignificant change in albumin, globulin and total protein levels. These results are in accordance with [32], who observe an increase in serum total protein, albumin and globulin when male rats were consumed with tartrazine at low and high dose for 30 days. Furthermore our results are also in accordance with [31], who found an increase in concentration of serum total protein and albumin when diet of rats was supplemented with chocolate colors A and B.

The increase in concentration of serum proteins due to orange red dye may be due to stimulation of translation to synthesize the specific proteins required for all processes. Similarly the increase in serum globulin concentration is correlated with increased 
immunoglobulin synthesis, the defense system which works to keep the body protective from the negative effects of the food dye.

\section{ACKNOWLEDGMENTS}

We are very much thankful to University grants commission for providing financial assistance and Centre of Research for Development (CORD), University of Kashmir, India for providing full time support and all laboratory facilities.

\section{REFERENCES}

1. Sharma S, Goyal RP, Chakravarty G, Sharma A. Toxicity of tomato red, a popular food dye blend on male albino mice. Experimental and Toxicologic Pathology. 2008;60(1):51-7.

2. Anna H, Christian RV. The potential use of organically grown dye plants in the organic textile industry. Experiences and results on the cultivation and yields of dyers chamomile (Anhemis tinctoria L.), Dyers Knotweed (Polygonum tinctoria) and Weld (Reseda luteola L.). Journal of Sustainable Agriculture. 2003;23(2):17-40.

3. Hussein SA, Barakat HH, Merfort I, Nawwar MA. Tannins from the leaves of Punica granatum. Phytochemistry. 1997;45(4):819-23.

4. Macioszek VK, Kononowicz AK. The evaluation of the genotoxicity of two commonly used food colors: Quinoline Yellow (E 104) and Brilliant Black BN (E 151). Cellular and Molecular Biology Letters. 2004;9(1):107-22.

5. Anliker R. Ecotoxicology of dyestuffs a joint effort by industry. Ecotoxicology and environmental safety. 1979;3(1):59-74.

6. Turkoglu S. Genotoxicity of five food preservatives tested on root tips of Allium cepa. Mutation Research/Genetic Toxicology and Environmental Mutagenesis. 2007;626(1-2):414.

7. Tsuda S, Murakami M, Matsusaka N, Kano K, Taniguchi K, Sasaki YF. DNA damage induced by red food dyes orally administered to pregnant and male mice. Toxicology Science. 2001;61(1):92-99.

8. Montaser MM, Alkafafy ME. Effects of Synthetic Food Colour (Carmoisine) on Expression of Some Fuel Metabolism Genes in Liver of Male Albino Rats. Life Science Journal 2013;10(2): 2191-98.

9. Ali MO, Sharaf AK, El-Deen OM, El-Menshay OM, Bakery S. Genotoxic effects of fluoxetine on the chromosomes of bone marrow cells of pregnant mice. 39th Annual International Meeting, The International Association of Forensic Toxicologists TIAFT. 200, 2001, 27.

10. Tema Nord. Food additives in Europe 2000; Status of safety assessments of food additives presently permitted in the EU, Tema Nord. 2002;560:116-121.

11. Mathur NRA, Chaudhary V, Mehta M, Krishnatrey R. Effect of Sunset Yellow on testis in rats. Journal of Ecophysiology and Occupational Health. 2005;5(1):1-3

12. Poul M, Jarry G, Elhkim MO, Poul JM. Lack of genotoxic effect of food dyes amaranth, Sunset Yellow and Tartrazine and their metabolites in the gut micronucleus assay in mice. Food and Chemical Toxicology. 2009;47(2):443-448.

13. Westmoreland C, Gatehouse DG. The differential clastogenicity of Solvent Yellow 14 and FD \& C Yellow No. 6 in vivo in the rodent micronucleus test (observations on species and tissue specificity). Carcinogenesis. 1991;12(8):1403-1407.
14. Orban N, Boldizsar I, Szucs Z, Danos B. Influence of different elicitors on the synthesis of anthraquinone derivatives in Rubia tinctorum L. cell suspension cultures. Dyes and Pigments. 2008;77(1):249-257.

15. Ozen E, Yeniocak M, Goktas O, Alma MH, Yilmaz F. Antimicrobial and antifungal properties of madder root (Rubia tinctorum) colorant used as an environmentallyfriendly wood preservative. Bioresources. 2014;9(2):19982009.

16. Reitman S, Frankel S. A colorimetric method for the determination of serum glutamic oxalacetic and glutamic pyruvic transaminases. American journal of clinical pathology. 1957;28(1):56-63.

17. Belfield A, Goldberg D. Colorimetric determination of alkaline phosphatase activity. Enzyme. 1971;12(5):561-568.

18. Doumas BT. Standards for total serum protein assay-a collaborative study. Clinical Chemistry. 1975;21(8):1159-1166.

19. Lanter AL. Clinical Biochemistry W. B. Saunders Company, Philadelphia, 7 th edition, 1975, 147-159.

20. Rodak LC. Routine testing in haematology. In: Diagnostic haematology. W.B. London, Toronto. 1995, PP. 128-144.

21. Jain NC, Schalm's Veterinary Heamatology, $4^{\text {th }}$ Ed., Lea and Fabiger, Philadelphia, 1986.

22. Macioszek VK, Kononowicz AK. The evaluation of the genotoxicity of two commonly used food colours; Quinoline Yellow (E104) and Brilliant Black BN (E151). Cellular and Molecular Biology Letters. 2004;9(1):107-122.

23. Shaker AMH, Ismail IA, El-Nemr SE. Effect of different food stuff colorants added to casein diet on biological evaluation. Bull. Nutr. Inst. Cairo. 1989;9(1):77-86.

24. Tsuda S, Murakami M, Matsusaka N, Kano K, Taniguchi K, Sasaki YF. DNA damage induced by red food dyes orally administered to pregnant and male mice. Toxicology Science. 2001;61(1):92- 99

25. Babu S, Shenolikar IS. Health and nutritional implications of food colors. Indian Journal of Medical Research. 1995; 102:245-249.

26. Yuan G, Dai S, Yin Z, Lu H, Jia R, Xu J, Zhao X. Toxicological assessment of combined lead and cadmium: Acute and subchronic toxicity study in rats. Food and Chemical Toxicology. 2014;65:260-268.

27. Alsolami MA. Effect of a food additive on certain haematological and biochemical parameters in male albino rat. International Journal of Zoology and Research. 2017;7:110.

28. Ates B, Orun I, Talas ZS, Durmaz G, Yilmaz I. Effects of sodium selenite on some biochemical and hematological parameters of rainbow trout (Oncorhynchus mykiss Walbaum, 1792)exposed to $\mathrm{Pb}^{2+}$ and $\mathrm{Cu}^{2+}$. Fish Physiology and Biochemistry. 2008;34(1):53-59.

29. Govindwar SP, Dalvi RR. Age dependent Toxicity of a corn extract in young and old male rats. Veterinary and Human Toxicology. 1990;32(1):23-26.

30. Mekkawy HA, Ali MO, El-Zawahry AM. Toxic effect of syntheticand natural food dyes on renal and hepatic functions in rats. Toxicology Letters. 1998;95(1001):155-155.

31. Aboel-Zahab H, El-Khyat Z, Sidhom G, Awadallah R, AbdelAl W, Mahdy K. Physiological effects of some synthetic food colouring additives on rats. Bollettino Chimico Farmaceutico. 1997;136(10):615 - 627.

32. Amin KA, Hameid HA, Elsttar AA. Effect of food azo dyes tartrazine and Carmoisine on biochemical parameters related to renal, hepatic function and oxidative stress biomarkers in young male rats. Food and Chemical Toxicology. 2010;48(10):2994-2999.

HOW TO CITE THIS ARTICLE: Khan IS, Ali MN, Murtaza M. Effect of Synthetic Red Dye Orange Red and Natural Red Dye Alizarin on Biochemical and Hematological Parameters in Male Wistar Rats. Int. J. Pharm. Sci. Drug Res. 2019; 11(5): 221-225. DOI: 10.25004/IJPSDR.2019.110511 